\title{
Using social media for research during COVID-19 pandemic in a cohort in Rio Grande do Sul state, Brazil
}

\author{
Uso de mídias sociais para pesquisa durante a pandemia de COVID-19 em uma \\ coorte no estado do Rio Grande do Sul, Brasil
}

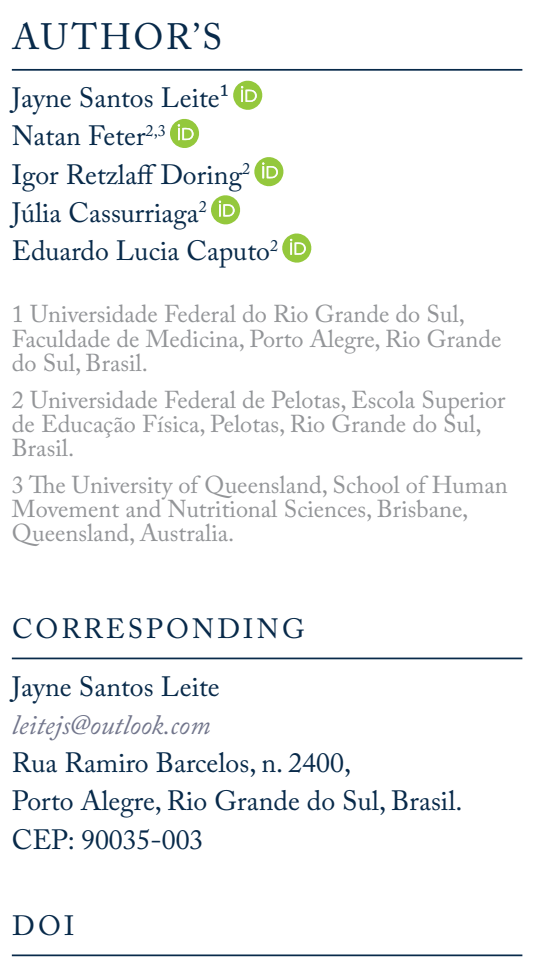

$10.12820 /$ rbafs. $25 \mathrm{e} 0154$

\begin{abstract}
We aim to share our experience of participants recruitment for the Prospective Study about Mental and Physical Health (PAMPA) cohort study using social media. The recruitment strategies were based mainly on social media. The inclusion criteria were being 18 years old or more and resident of Rio Grande do Sul state. In the survey's official Facebook ${ }^{\oplus}$ and Instagram ${ }^{\circledast}$ page some strategies were adopted, such as weekly posting schedule, use of hashtags, organic publications, and boosted publications. Over the first 13 days of study, 1773 people were reached by an organic engagement. Boosted campaigns increased the average interactions reaching a total of 34,376 people, leading to 857 clicks on the survey's link. Social media is a useful tool for participants recruitment strategy in epidemiological researches. However, internet-based approaches aiming to reach a more heterogeneous sample should be developed.
\end{abstract}

Keywords: Social networking; Longitudinal studies; Research design; Methods.

RESUMO

O objetivo deste estudo écompartilhar nossa experiência de recrutamento de participantes através das redes sociais para coorte PAMPA (Estudo Longitudinal sobre a Saúde Física e Mental). As estratégias de recrutamento utilizadas basearam-se principalmente nas redes sociais. Os critérios de inclusão eram ter 18 anos ou mais de idade, e ser residente no estado do Rio Grande do Sul. Na página oficial do estudo, no Facebook ${ }^{\circ}$ e Instagram ${ }^{\circ}$, foram adotadas algumas estratégias como programação de postagens semanais, uso de hashtags, publicações orgânicas e publicação impulsionada. Nos primeiros 13 dias de desenvolvimento do estudo, 1.773 pessoas foram alcançadas por um envolvimento orgânico. As campanhas pagas aumentaram a média de interaçôes, atingindo um total de 34.376 pessoas, resultando em 857 cliques no link da pesquisa. Redes sociais são uma ferramenta útil para recrutamento em pesquisas epidemiológicas. No entanto, abordagens baseadas em internet e que visem atingir uma amostra mais heterogênea devem ser desenvolvidas.

Palavras-chave: Rede social; Estudos longitudinais; Projetos de pesquisa; Métodos.

\section{(cc) BY}

This work is licensed under a Creative Commons Attribution 4.0 International License.

\section{Introduction}

The COVID-19 pandemic changed the way people are communicating. As people should stay home due to social distancing rules imposed by governments to reduce the new coronavirus (Sars-CoV-2) spread, use of social media has increased ${ }^{1}$. Such increase was also observed in research groups, which started or intensify the use of these tools to share their works, and reach possible research participants. However, even before the COVID-19 pandemic, online surveys were alrea- dy used, and their applicability to the science field has been explored previously ${ }^{2}$. Nevertheless, at the same time social media appears as an easy and lower cost way of recruiting research participants and sharing study results, these methods present some challenges and might incur in selection bias ${ }^{3,4}$.

In this paper, we aim to share our experience of participant's recruitment of the PAMPA (Prospective Study about Mental and Physical Health) cohort study using social media. The assessments of this study were 
planned to be fully online, since face-to-face approaches are not allowed to avoid the virus spread.

\section{Methods}

The Rio Grande do Sul state government adopted a social distancing flag system, in which each region received a flag color (yellow, orange, red or black) ${ }^{5}$. Seven health macro-regions were established (Sul, Centro-Oeste, Vales, Metropolitana, Missioneira, Norte and Serra, in Portuguese). This study was approved by the local Ethics and Research Committee (CAAE: 31906920.7.0000.5313).

The sample size calculation was based considering the prevalence of the three primary outcomes of the PAMPA cohort study (i.e., depression and anxiety, low back pain, and healthcare system access). The required sample size was estimated in 1,764 participants ${ }^{6}$. An ideal number of participants was estimated for each state region, as follows: $\operatorname{Sul}(\mathrm{n}=165)$, Norte $(\mathrm{n}=198)$, Centro-oeste $(\mathrm{n}=156)$, Missioneira $(\mathrm{n}=143)$, Metropolitana $(\mathrm{n}=777)$, Vales $(\mathrm{n}=142)$, and in Serra $(\mathrm{n}=185)$, as illustrated in Figure 1.

The inclusion criteria were being at least 18 yearsold and resident at the Rio Grande do Sul state. Due to internet-based recruitment, no specific exclusion crite- ria were adopted. More details on the study's methodology might be found elsewhere ${ }^{6}$.

Although participants have been recruited by a four-arm approach, the social media have received special attention during data collection. In addition to the three other recruitment strategies used (Universities e-mail contact, local media, and personal contacts), a social media strategy was designed via Facebook ${ }^{\circledR}$ and Instagram ${ }^{\circledR}$, aiming to share the questionnaire link with as many people as possible. For this purpose, the researchers involved in the PAMPA cohort study, have been on weekly online meetings to previously plan all publications in the social media pages.

In order to increase publications' reach and study visibility, some strategies for publishing and disseminating content were used. Initially, a weekly posting schedule was structured, in which posts were supposed to encourage participation. From that, visually attractive posts were made to arouse followers' curiosity and make them engage in the study and answer the questionnaire ${ }^{7}$. In every publication, short texts with hyperlinks were used in the first lines of the paragraph, to direct the reader to the study's questionnaire link.

During the data collection period, the Rio Grande do Sul maps were weekly posted aiming to inform peo-

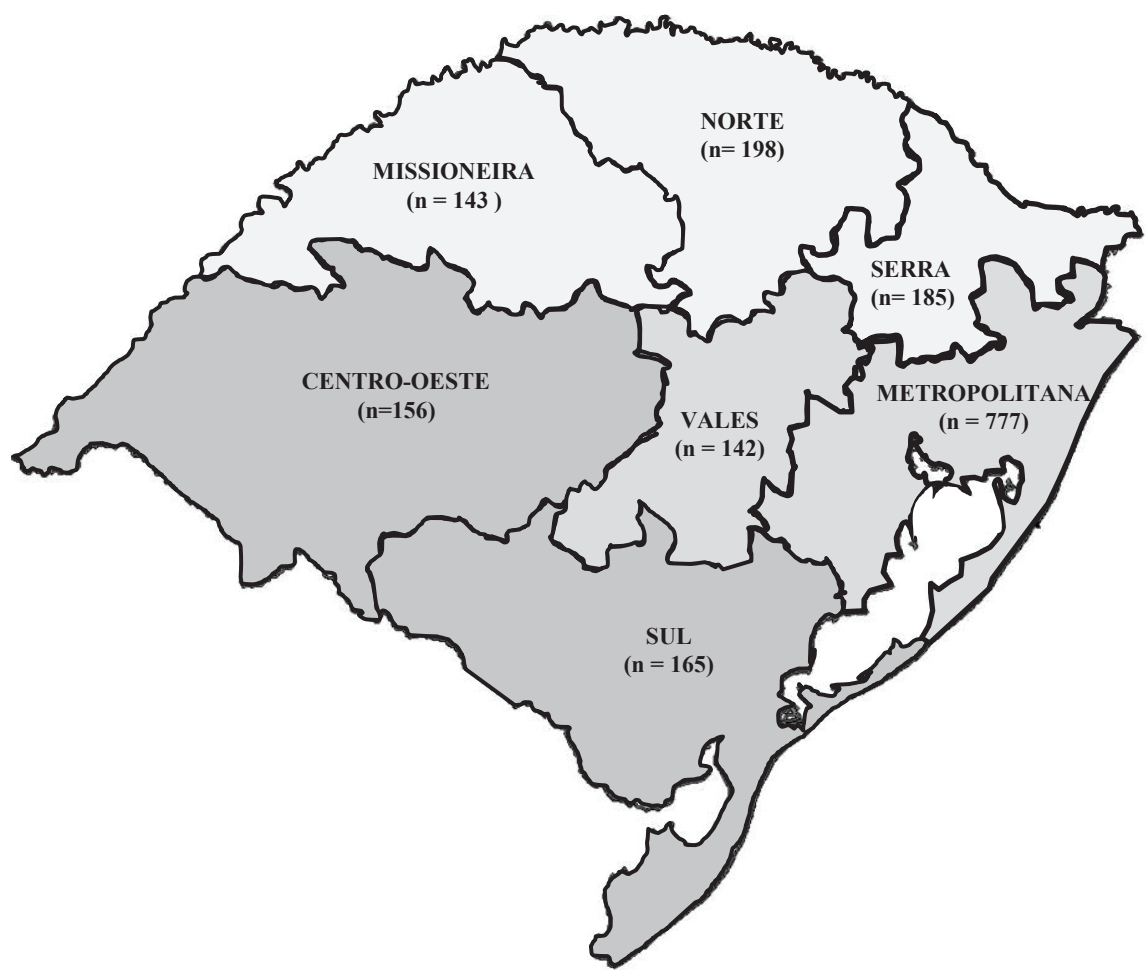

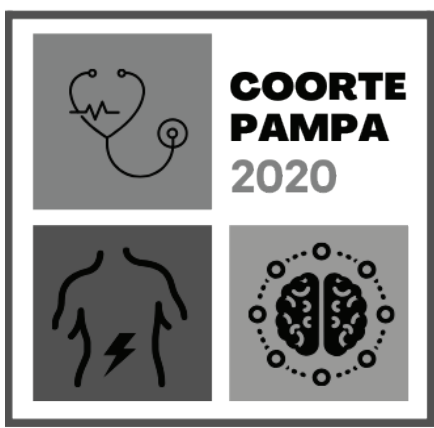

PROSPECTIVE STUDY ABOUT MENTAL AND PHYSICAL HEALTH

Figure 1 - Example of informative map's post with the number of participants required in each macro-region of the state of Rio Grande do Sul, Brazil, 2020. 
ple about the research progress, showing the prevalence of reached respondents in each region of the state. As well as engage participants in both platforms (Facebook $^{\circledR}$ and Instagram ${ }^{\circledR}$ ), weekly posts were planned to explain the study's aim, as well as its scientific method, contribution of scientific research, how the results could help the population, what is a cohort study, and who are the PAMPA research team were posted. This strategy aimed to approximate university and the state population, to demonstrate reliability to the participants. These publications were posted in business days during the data collection period. Also, stories on Instagram ${ }^{\circledR}$ had an important function to promote interaction with people that follow the PAMPA cohort official page.

Hashtags (\#) were also used to facilitate searches for content and mentions, as well as to direct the study's link to municipal and state agencies. When a keyword is used on the hashtag search bar, the content exposed in the post should be displayed. This is a highlighting strategy to signal the topics that the post is dealing with. In addition, hashtags contribute to people in the search of specific themes and related content ${ }^{8}$. Thus, hashtags favor to broaden the reach of posts, and possibly, activate the target audience on social media ${ }^{9,10}$.

All posts were shared in the "stories" option of study's social media accounts, always followed by mentions and location pinning. These posts were also sent via Instagram ${ }^{\circledR}$ ' “ "direct” to public agencies profiles and the state of Rio Grande do Sul official media, as well as shared by several public Facebook ${ }^{\circledR}$ groups. The posts were interspersed between informational and content. Informative posts contained the image of Rio Grande do Sul map, which was personalized to represent the advances in the response rates of the survey in each macro-region. As the response rates increased, the colors of the map became more intense. Maps were posted twice a week, and were designed so that participants could visually monitor the data collection progress. In addition, each of the seven health macro-regions had its own map displaying the responses progress. In parallel, three content posts were made weekly, presenting the study objectives, team, importance of community participation, among others, briefly and informatively.

An organic strategy was adopted for most of the posts. Nevertheless, organic engagement requires to maintain a regular frequency in posts to reach a higher number of followers. Further, when the number of recruited participants plateaued, the boosted posts strategy was adopted. To minimize selection bias, we only filter the campaign for regions where the number of participants were lower than the overall average of achieved. No filters for sex, age, and personal interests were applied.

\section{Results}

We completed the recruitment phase with 2,321 participants. Most of them were female $(76.6 \%, 95 \% \mathrm{CI}$ : 74.4 ; 78.7), white skin color $(76.6 \%, 95 \% \mathrm{CI}$ : 74.4\%; 78.7), middle-aged (38.2 years old, 95\%CI: $37.5 ; 38.9$ ), and with high school $(90.6 \%, 95 \% \mathrm{CI}: 89.0 ; 92.0)$. Over the first 13 days of study development, 1,773 (76.4\%) respondents were reached by organic engagement. However, from the $14^{\text {th }}$ day onwards, a plateau in the number of responses was noted, in five of the seven regions. Therefore, a video was created to spread the study, being the first boosted post. Unlike organic posts, the boosted ones require a financial investment, so that it is entitled to a place of prominence and greater visibility.

The amount invested to promote the posts in our social media accounts was $\mathrm{R} \$ 11.50$ Brazilian reais per day in two different campaigns. In the first, posts were promoted for a total of seven days and targeted the regions with the lowest rate of survey responses (i.e. Norte and Missioneira). In the second and last campaign, we switched the target regions to Metropolitana, Serra, and Vales during the last 10 days of data collection. These regions were selected intentionally due to the lower number of interactions on the survey's Facebook ${ }^{\circledR}$ page. These paid campaigns increased the average interactions reaching a total of 34,376 people, leading to 857 clicks on the survey's link and 50 comments in the publications. Nevertheless, we noted that in the two consecutive days when 40 and 50 users clicked in our survey's link, no responses from the questionnaire were recorded.

\section{Discussion}

The demographic characteristics of our sample were similar to the general population of the Rio Grande do Sul state (i.e., majority women and white) ${ }^{11}$. Most of participants were reached by organic publications. Even though this strategy had no financial cost, researchers needed to be aware when designing the posts to increase visibility and consequently, participant's engagement ${ }^{12}$. For this purpose, some dissemination strategies were defined, such as a fixed time for the posts (at the beginning of the day) and sharing the photos on stories option to increase their visibility. In contrast, it was expected, by using boosted posts, that a larger number of participants were reached, in less time ${ }^{13}$. 
Even with boosted publication, the target number of participants in each region was not achieved. Some reasons for this might be suggested. First, the research team did not have contacts or active working network with other institutions located in some regions (i.e., Missioneira, Norte, Vales). Also, people living in regions with federal universities are more used to participate in researches, which might explain the low response rate in those regions without these institutions. Second, the Missioneira, Serra, and Vales were regions with more rural zones. This might have affected the spread of the survey's link as the use and access of internet in rural areas is lower than urban areas ${ }^{14}$.

Although the required number of participants in some regions were not achieved, a larger number of people in less time were reached ${ }^{13}$. The value invested in social media campaign may vary according to the number of people to be reached. In this way, social media companies such as Facebook ${ }^{\otimes}$ encourage the user to do a greater financial investment to achieve a broader population. The stability observed in the number of respondents, even using a boosted post may indicate that although the survey's link spread is important for visibility, it may not represent a greater sample size.

Therefore, further researches may focus on understanding the determinants for participation in online-based surveys, so that a more efficient sample recruitment strategy can be designed to facilitate a broader and greater sample size. We also faced some challenges in this process, which should be listed. We experienced blockages for activities such as following new users' profiles (Instagram ${ }^{\circledR}$ ), and sending messages with the survey questionnaire link, on both social networks (Instagram ${ }^{\circledR}$ and Facebook ${ }^{\circledR}$ ). Such networks mistook us for robots ${ }^{15}$, possibly because more than one researcher logged in the study's profile, as the activities were carried out systematically. In addition to posts, finding and following new profiles, were among the actions carried out to reach new possible respondents. Also, a message with the study link and explaining the purpose of the study was shared with as many people as possible through the messaging system. These contacts made through the sending of messages were made on both social networks already mentioned, were directed to the City Halls in each region of the state, universities, research groups, businesses, stores, restaurants, personal profiles, among others, so that the link of the study reached the participants in different contexts, without any distinction among profile type.
The number of responses achieved by two promoted posts was less than expected as the target number of participants in the directed regions were not reached after the boosted posts. However, this may be related to the need of a greater financial investment on social media, so that posts can reach more people. Also, we have to note that as with other research methodologies, researching in a completely online context presented some easiness, as well as limitations ${ }^{2,3}$. The first point to be highlighted is the selection bias due to the potential different characteristics by the responders and not responders. For this purpose, it is important to keep in mind that internet use is not equally distributed in the Brazilian population. Internet is less used by older people, individuals with low income and educational level, and living in rural areas ${ }^{14}$. Another important factor for conducting online recruitment is to ensure that participants' data are secure and private ${ }^{4}$. Furthermore, faceto-face interviews were not allowed by the National Ethics Commission. Then, social media made possible to perform a state-level, population-based study during the COVID-19 pandemic.

In conclusion, besides the challenges to conduct a web-based survey, social media is a useful and low-cost strategy for recruitment in epidemiological researches. As physical activity patterns have been affected during the COVID-19 pandemic, researches in the field of physical activity and health are warranted to bring light into the discussion on possible strategies to restore and improve physical activity practice at populational level as restrictions are eased. Although approaches aiming to reach a more heterogeneous sample might be developed, we expected our findings provide support to future internet-based researches in this field.

\section{Conflict of interest}

The authors declare no conflict of interest.

\section{Authors' contributions}

Leite JS, Feter N, Doring IR, Cassuriaga J, and Caputo EL contributed to study conception and design, data analysis and interpretation, writing, and relevant critical review of the manuscript's intellectual content, final approval of the version to be published; and guarantee the study accuracy and integrity.

\section{Acknowledgments}

This study was financed in part by the Coordenação de Aperfeiçoamento de Pessoal de Nível Superior - Brasil (CAPES) - Finance Code 001. 


\section{References}

1. Hussain W. Role of Social Media in COVID-19 Pandemic. Int J Front Sci. 2020;19(4):59-60.

2. Boni RB. Websurveys nos tempos de COVID-19. Cad Saúde Pública. 2020;36(7): e00155820.

3. Christensen T, Riis AH, Hatch EE, Wise LA, Nielsen MG, Rothman KJ, Toft Sørensen H, Mikkelsen EM. Costs and Efficiency of Online and Offline Recruitment Methods: A Web-Based Cohort Study. J Med Internet Res. 2017;1;19(3):e58.

4. Gelinas L, Pierce R, Winkler S, Cohen IG, Lynch HF, Bierer BE. Using Social Media as a Research Recruitment Tool: Ethical Issues and Recommendations. Am J Bioeth. 2017;17(3):3-14.

5. Governo do Estado do Rio Grande do Sul. DECRETO N.o 55.240, DE 10 DE MAIO DE 2020 [Internet]. 2020 Available from <https://planejamento.rs.gov.br/normativasdistanciamento> [2020 Sep].

6. Feter N, Caputo EL, Doring IR, Leite JS, Cassuriaga J, Reichert FF, et al. Longitudinal study about low back pain, mental health, and access to healthcare system during COVID-19 pandemic: protocol of an ambispective cohort. medRxiv. Cold Spring Harbor Laboratory Press; 2020:1-11. Available from: <https://www.medrxiv.org/ content/10.1101/2020.07.22.20160309v1> [2020 Sep].

7. Grandi MLC, Flores N. Estratégias de engajamento de pesquisadores nas mídias sociais do periódico ciência rural. Rev do EDICC. 2020;6:311-22.

8. Fonseca MN, Accioly NS, Garcias C, Ferentz L. Hashtags related to Covid-19 in Brazil: the usage during the beginning of the social isolation. Com Ciências Saúde.2020;31(1):131-43.
9. Canaltech. O que é hashtag? [cited 2020 ago 15]. Available from: <https://canaltech.com.br/produtos/O-que-e-hashtag/>

10. Hashtag: o que significa e como usar \#hashtag nas redes sociais?. Resultados digitais [cited 2020 ago 15]. Available from <https://resultadosdigitais.com.br/blog/o-que-ehashtag $>$ [2020 Sep].

11. Brasil. Instituto Brasileiro de geografia e Estatística. Censo demográfico 2010 [serial on internet] 2010 Available from: <https://censo2010.ibge.gov.br/> [2020 Sep].

12. Moraes D. Entenda o que é tráfego orgânico e por que ele é essencial para sua estratégia online. 2018. Available from: <https://rockcontent.com/br/blog/o-que-e-trafegoorganico> [2020 Ago].

13. Lucca D, Galeazzi TL. O instagram como estratégia de marketing digital na empresa nutriativa. Santa Catarina. Instituto Federal de Santa Catarina; 2019.

14. Centro Regional de Estudos para o Desenvolvimento da Sociedade da Informação. Painel TIC COVID-19 pesquisa sobre o uso da internet no Brasil durante a pandemia do novo coronavírus. 2020. Available from: <https://cetic.br/ media/docs/publicacoes/2/20200930180249/painel_tic_ covid19_2edicao_livro\%20eletr\%C3\%B4nico.pdf> [2020 Oct].

15. Souza DC. Ciência em rede: o potencial dos periódicos científicos para divulgação no Facebook $^{\circledR}$ e educação [dissertação de mestrado]. Rio de Janeiro: Instituto Oswaldo Cruz, Fundação Oswaldo Cruz; 2019.

Received: $11 / 09 / 2020$

Approved: 31/10/2020 